\section{TP Periodica Polytechnica \\ Chemical Engineering}

59(1), pp. 3-15, 2015

DOI:10.3311/PPch.7257

Creative Commons Attribution (i)

RESEARCH ARTICLE

\title{
Cyclopropanation of Some Alkaloids
}

Péter KEGLEVICH ${ }^{1}$, László HAZAI ${ }^{1}$,
György KALAUS ${ }^{1}$, Csaba SZÁNTAY ${ }^{1}$

ReCEIVEd 13 January 2014; ACCEPT AFTER REVISION 14 JuLy 2014

\begin{abstract}
New derivatives of natural compounds, galanthamine using in treatment of Alzheimer's disease and antitumor dimer alkaloids vinblastine and vincristine were synthesized. In the course of the reaction between galanthamine and diazomethane in the presence of a catalyst, such as palladium(II) acetate or copper(I) bromide, methylene insertion into the aromatic ring was observed instead of the expected cyclopropanation of the carbon-carbon double bond. New vindoline derivatives conjugated with amino acid esters were prepared. In SimmonsSmith reaction vinblastine and vincristine cyclopropanated in the carbon carbon double bond in position 14 and 15 of the vindoline monomer were obtained. New dimer alkaloids showed significant inhibiting effects in several tumor cell lines.
\end{abstract}

\section{Keywords}

galanthamine, methylene insertion, cyclopropano-vinblastine, cyclopropano-vincristine, antitumor activity

\footnotetext{
${ }^{1}$ Department of Organic Chemistry and Technology, Faculty of Chemical Technology and Biotechnology, Budapest University of Technology and Economics, H-1521 Budapest, P. O. B. 91, Hungary

*Corresponding author, e-mail: szantay@mail.bme.hu
}

\section{Introduction}

Among the alkaloids and alkaloid-like compounds there are many biologically active derivatives with useful effects on some diseases. By structural modification of that compounds we can hopefully have even more useful derivatives. Several possibilities can be investigated. We tried the effect of introduction of cyclopropane ring into some alkaloids or alkaloidlike compounds.

\section{Results and discussion}

\subsection{Galanthamine derivatives [1]}

Galanthamine [2] (1) is a member of the Amaryllidaceae alkaloids, isolated from the Caucasian snowdrop (Galanthus woronowii) [3]. Galanthamine is a butyrylcholinesterase and acetylcholinesterase inhibitor [3,4] as well as an allosterically potentiating ligand of the neuronal nicotinic receptor, [5] currently used for the treatment of Alzheimer's disease $[5,6]$.

Many reports have described different synthetic routes to prepare galanthamine [2,7-14], and with systematic transformations of its cyclic structure a number of derivatives were synthesized; e.g. by changing the position of the nitrogen atom in the azepine $d$ ring [15], building in a sulfone group in ring $d$ in place of the nitrogen atom [16], and substituting the furan $b$ ring with pyrrole [17]. Derivatives without a furan $b$ ring [18], compounds containing a nitrogen heteroatom in the aromatic ring $a$ [19] and galanthamine with an opened azepine $d$ ring were also investigated [20]. The last result in the chemistry of galanthamine was the synthesis of homogalanthamine (2) with a larger azepine ring [21].

A study of the literature data presented above led us to the concept of attempting to change the $c$ ring by considering the carbon-carbon double bond as a target. The saturated derivative of galanthamine is known as lycoramine [3] and has a weaker biological effect, but the cyclopropano derivative (3) is unknown in the literature.

The cyclopropane subunit has always been considered as an electronically unique $[22,23]$ structural element not only in the chemistry of artificial molecular structures [24] but in natural compounds as well [25-27]. Synthetic methods for the cyclopropanation of carbon-carbon double bond were reviewed 


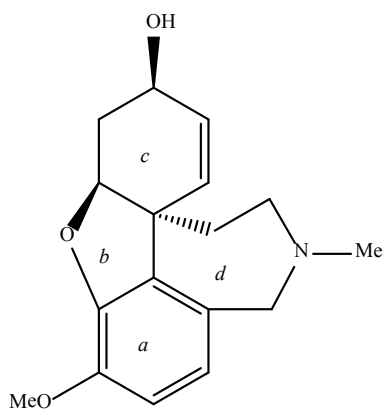

1





1
4

<smiles>COc1ccc2c3c1O[C@@H]1CC[C@@]3(C2CN(C)S(C)(=O)=O)C2CC2[C@@H](O)C1</smiles>
3<smiles>COc1ccc2c3c1O[C@H]1C[C@H](O)C4CC4[C@@]3(CCN(C)C2)C1</smiles>

3

Scheme 1

recently [28], the Simmons-Smith reaction [29,30], reaction with dimethyloxosulfonium methylide [31], and cyclopropanation with diazomethane [32] in the presence of a catalyst are frequently used.

In our first approach to the cyclopropanation reaction of galanthamine (1) we used the Simmons-Smith method by allowing 1 to react with diiodomethane [29] in the presence of diethylzinc at $0{ }^{\circ} \mathrm{C}$ or using trifluoroacetic acid [30] besides the aforementioned reagents at $-15{ }^{\circ} \mathrm{C}$. However, from these reactions only decomposition products were isolated. Secondly, a reaction between 1 and diazomethane - generated from $N$ methyl- $N$-nitrosourea in dichloromethane solution in the presence of palladium(II) acetate [32] at $0{ }^{\circ} \mathrm{C}$ - resulted in a new derivative of galanthamine (Scheme 1). Cyclopropanation has not taken place but from the reaction mixture we could isolate a cycloheptatriene derivative (4) in $8 \%$ yield. Besides 4 a sideproduct with an open $d$ ring (5) could also be detected.

The formation of compound 4 occurs with insertion of a methylene group into the aromatic ring. The reaction is known in the literature and was mainly investigated in relatively simple aromatics to prepare tropylium salts with different substituents [33-36]. (The formation of compound 5 can be explained with an oxidative ring opening of $\mathbf{1} ; \mathrm{N}$-formylation reaction with diazomethane is known in the literature [37].)

According to the literature [33] the $\mathrm{Rh} / \mathrm{C}$ catalyst gives the best yields in these types of reaction and in some cases 


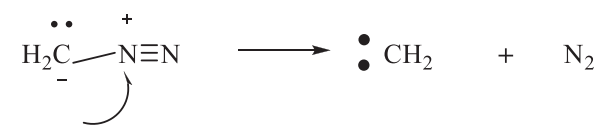

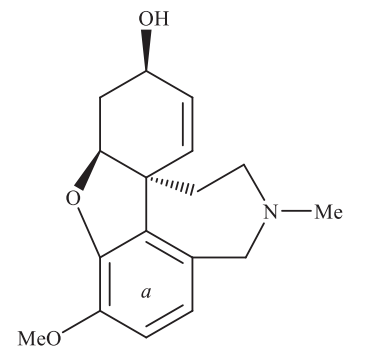

1



1a

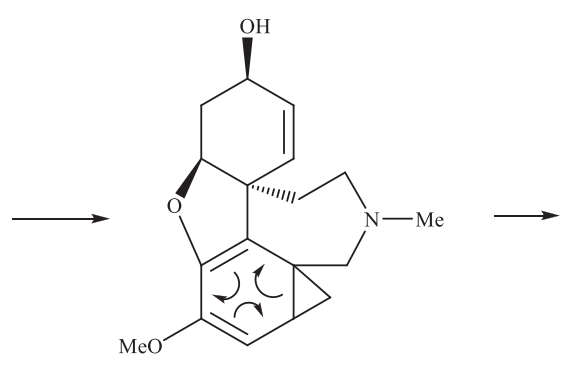

1b

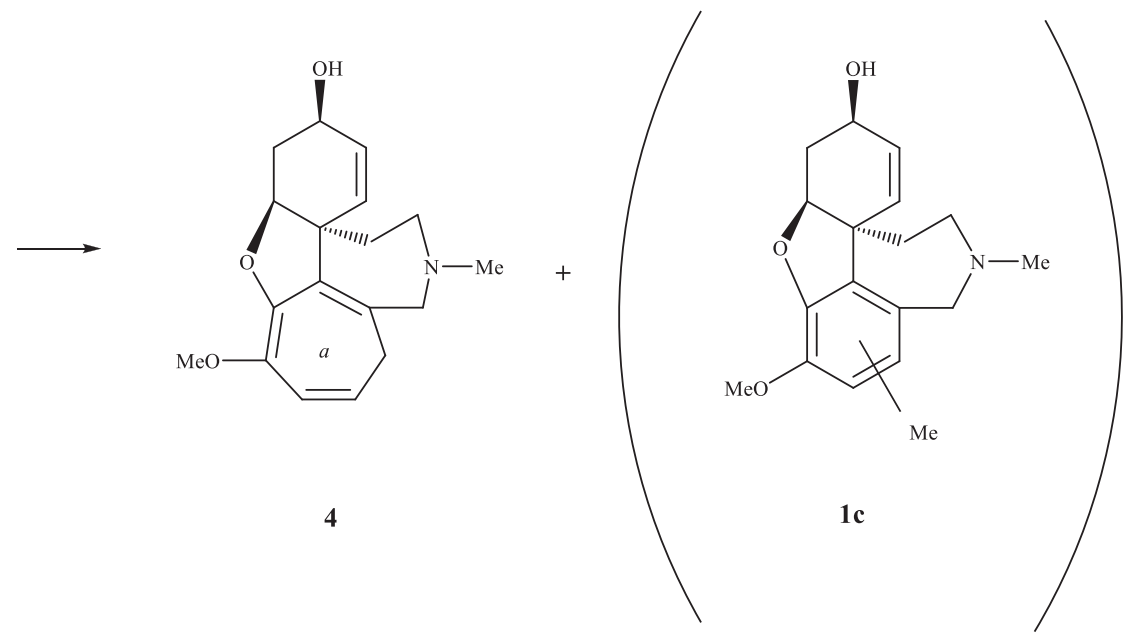

Scheme 2

copper(I) halogenides, copper(I) chloride [34] and copper(I) bromide $[35,36]$ were also effective. Using $\mathrm{Rh} / \mathrm{C}$ catalyst no reaction was observed between $\mathbf{1}$ and diazomethane. Performing the reaction in the presence of copper(I) bromide, however, the cycloheptatriene derivative $\mathbf{4}$ was isolated in $13 \%$ yield. Replacing diazomethane with trimethylsilyldiazomethane [38] proved to be unsuccessful.

Based on literature results [39] a possible mechanism is presented in Scheme 2. Carbene formed from diazomethane attaches to the aromatic $a$ ring (1a) producing the cycloheptatriene derivative (4) via a norcaradiene-type intermediate (1b).

Formation of an aromatic methyl derivative (1c) in this reaction is also possible, but no traces of this product were detected.

In summary, an attempted cyclopropanation of the carboncarbon double bond in the $c$ ring of galanthamine (1) with diazomethane resulted in a new derivative (4) with a cycloheptatriene structure in place of the aromatic $a$ ring. Such a reaction with methylene insertion into an aromatic ring has not yet been described in the field of natural compounds.

\subsection{Synthesis and in vitro antitumor effect of new} vindoline derivatives coupled with amino acid esters [40]

The dimeric alkaloids vinblastine (6) and vincristine (7) (Scheme 3) were isolated from the Madagascar periwinkle $\mathrm{Ca}$ tharanthus roseus. Both materials have been used in anticancer chemotherapy for more than forty years [41,42]. Vinblastine (6) is an antimicrotubule drug used to treat certain kinds of cancer, including Hodgkin's lymphoma, non-small cell lung cancer, breast cancer, head and neck cancer, and testicular cancer. Vincristine (7), the formyl derivative of vinblastine, can be used in various types of chemotherapy regimens. Its main uses are in non-Hodgkin's and Hodgkin's lymphoma, acute lymphoblastic leukemia, and in the treatment of nephroblastoma (Wilms tumor, a kidney tumor most common in young children). These dimeric alkaloids have two monomer alkaloid parts: vindoline (8) and catharanthine (9) (Scheme 3). Although the chemistry and pharmacology of vinblastine and vincristine are well known, and a number of their derivatives were synthesized to improve their therapeutic properties [43], however, vindoline and its derivatives were found to be biologically insignificant, 


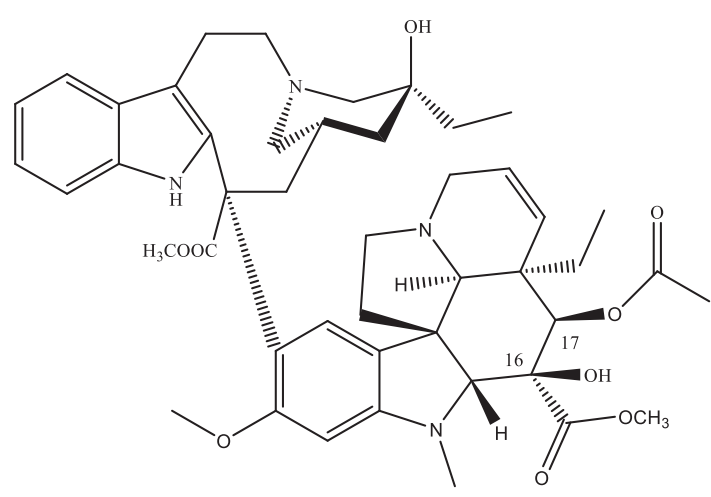

6

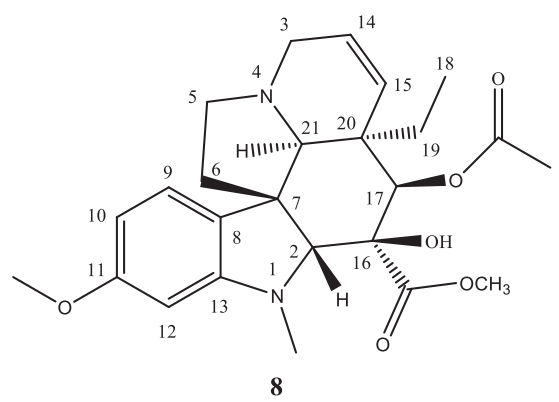

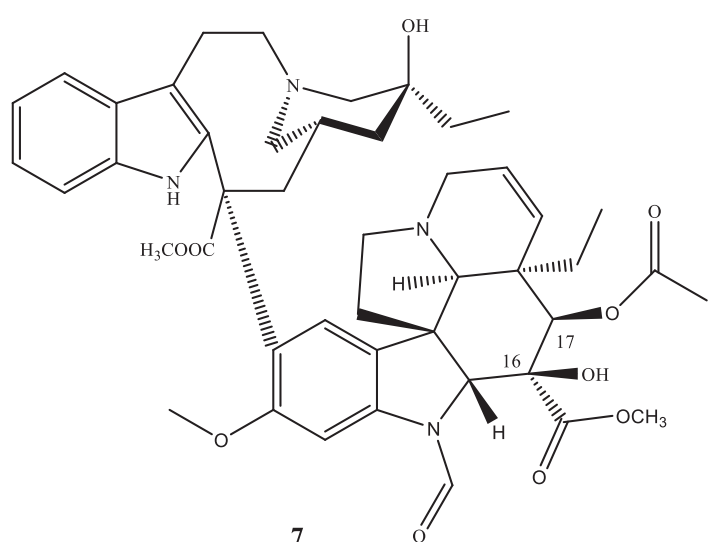

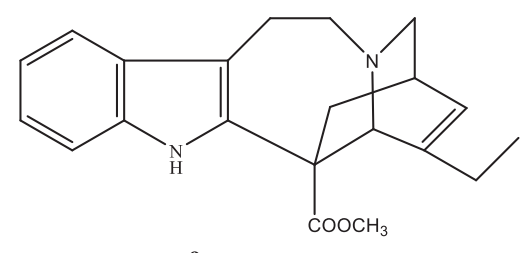

Scheme 3

therefore there is much fewer data on their chemistry and biological effect in the literature [44].

Our research project was conceived on the basis of two interesting experiences in connection with dimeric alkaloids.

Firstly, some amino acid derivatives of vinblastine and vincristine were synthesized by coupling amino acid esters with the vindoline part in position 16 [45]. The obtained conjugates exhibited significant antitumor effect against P388 and L1210 leukemia in mice. At the same time (D)- and (L)-tryptophan derivatives at the 16-position of desacetylvinblastine were conjugated through the carboxyl group with oligoarginine octapeptide as a carrier peptide at the $N$-terminus by Bánóczi et al. [46] One of the obtained stereoisomers showed a selective cytotoxic effect against the HL-60 human leukemia cells of higher proliferation rate.

Secondly, for dihydrovinblastine (i.e. vinblastine saturated in the 14,15-position of the vindoline part) a decreased antitumor activity and toxicity was observed, probably due to a different mechanism of action from vinblastine [47]. These observations suggest that amino acid conjugation and reduction of the 14,15-position both alter the mechanism of action. Based on these observations our goal was to couple vindoline (8), 14,15-dihydrovindoline, and vindoline condensed with a cyclopropane ring in position 14,15, with (L)- and (D)-tryptophan methyl ester at position 16 with a view to screening their biological effect. The azide coupling method known from peptide chemistry was used as the key step in the coupling of vindoline with the amino group of the amino acid ester.
The first task was to protect position 10 of vindoline, because in the presence of sodium nitrite used in the preparation of the corresponding azide, a nitrosation reaction took place in position 10, resulting in 10-nitrosovindoline [44]. In this procedure a bromo substituent was used to protect position 10 (Scheme 4).

10-Bromovindoline (10) was prepared by us from vindoline (8) in a simple bromination reaction using $N$-bromosuccinimide [44]. 14,15-Dihydrovindoline (11) is known from the literature [48], and was obtained by catalytic hydrogenation of vindoline (8). Analogously with the previous reaction, bromination of the saturated derivative 11 resulted in 10-bromo-14,15-dihydrovindoline (12). The cyclopropane ring was built into position 14,15 by a typical Simmons-Smith reaction from 10-bromovindoline (10) using diethylzinc and diiodomethane, yielding compound 13.

Hydrazides of 10-bromovindoline (14a), 14,15-dihydrovindoline (14b), and 14,15-cyclopropanovindoline (14c), were synthesized from the corresponding bromo esters 10-bromovindoline (10), 10-bromo-14,15-dihydrovindoline (12), and 10-bromo-14,15-cyclopropanovindoline (13), respectively, with hydrazine hydrate (Scheme 5). Hydrazine, as a strong nucleophile, caused desacetylation in position 17 during the reaction, and so the 17-desacetylated hydrazides were obtained as products.

Coupling the vindoline derivatives with tryptophan methyl esters was achieved by preparation of the azides (Scheme 6). The reaction of hydrazide 14a with sodium nitrite in methanol in the presence of hydrochloric acid resulted in azide 15a, which was then allowed to react without isolation with (L)tryptophan methyl ester to yield the vindoline conjugate $\mathbf{1 6 a}$. 




$\mathrm{R}=\mathrm{H} ; \mathbf{8}$
$\mathrm{R}=\mathrm{Br} ; \mathbf{1 0}$

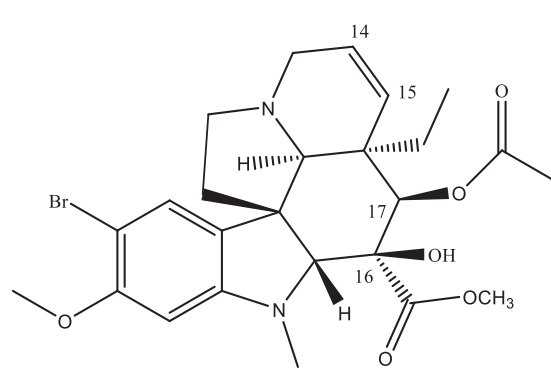

10







13

Scheme 4

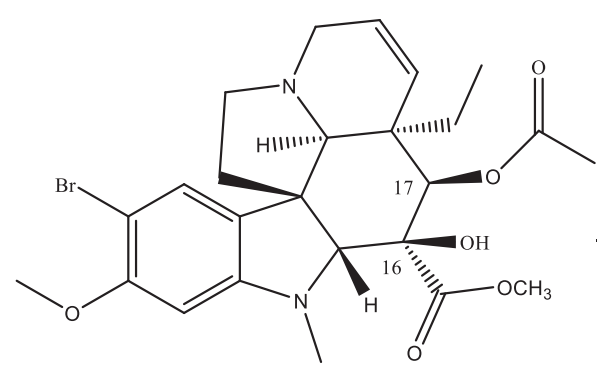

10



14b
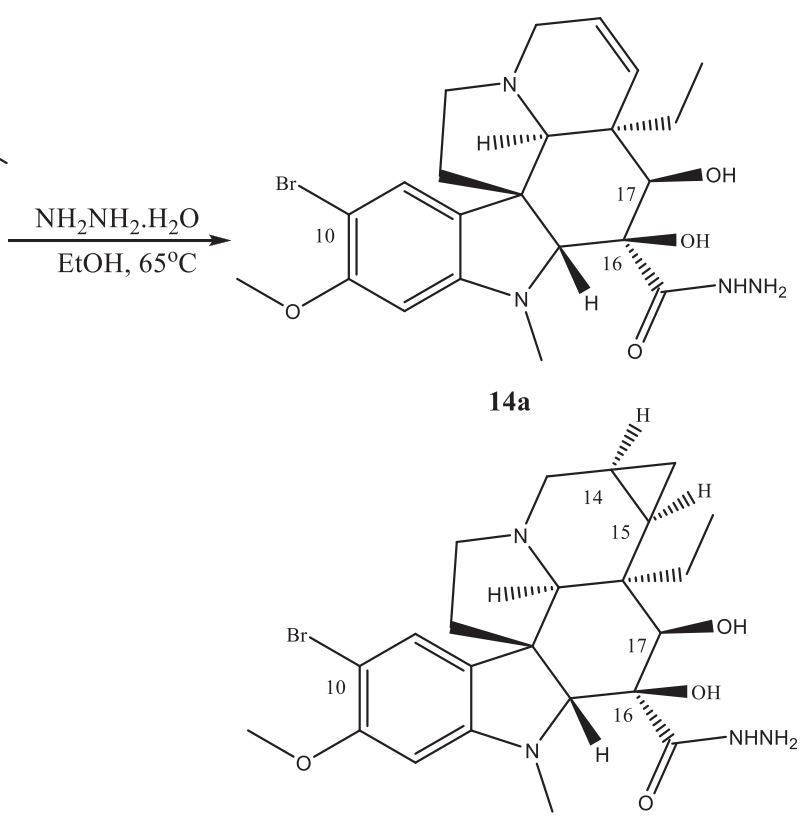

$14 c$

Scheme 5 


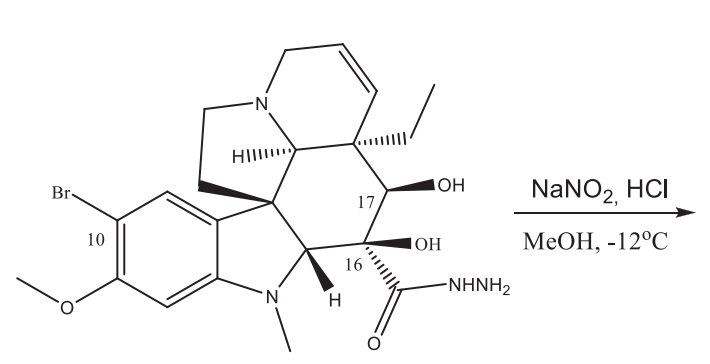

$14 \mathrm{a}$



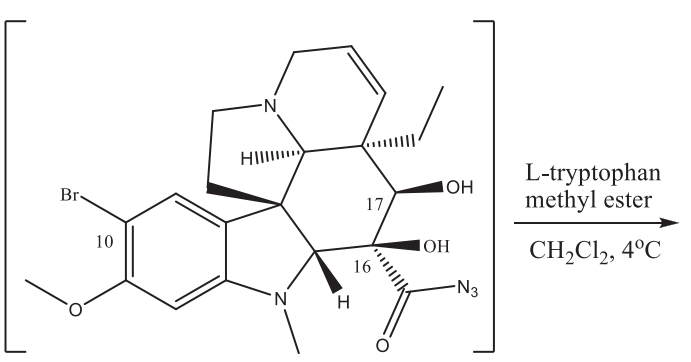

$15 \mathbf{a}$



$\mathrm{R}=\mathrm{Br} ; \mathbf{1 6 c}$
$\mathrm{R}=\mathrm{H} ; \mathbf{1 6 d}$ $\begin{aligned} & \mathrm{NaBH}_{4}, \mathrm{Pd} / \mathrm{C} \\ & \mathrm{MeOH}\end{aligned}$

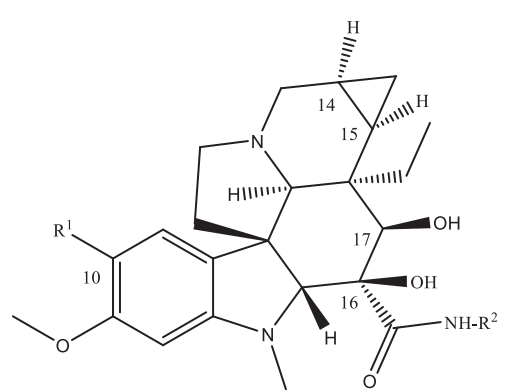

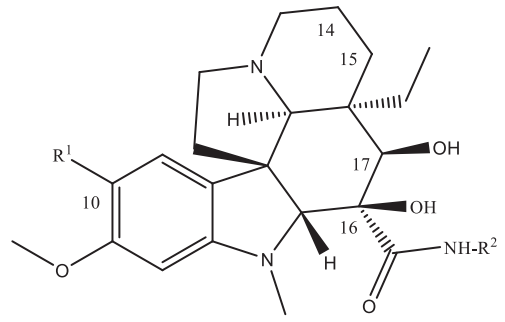

$\mathrm{R}^{1}=\mathrm{Br} ; \mathrm{R}^{2}=-(S)-\operatorname{Trp}-\mathrm{OCH}_{3} \mathbf{1 6 e}$ $\mathrm{R}^{1}=\mathrm{H} ; \mathrm{R}^{2}=-(S)-\mathrm{Trp}-\mathrm{OCH}_{3} \mathbf{1 6 f}$ $\mathrm{R}^{1}=\mathrm{Br} ; \mathrm{R}^{2}=-(R)-\operatorname{Trp}-\mathrm{OCH}_{3} \mathbf{1 6 g}$ $\mathrm{R}^{1}=\mathrm{H} ; \mathrm{R}^{2}=-(R)-\mathrm{Trp}-\mathrm{OCH}_{3} \mathbf{1 6 h}$



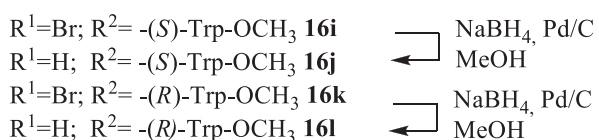

$\mathrm{R}^{1}=\mathrm{H} ; \mathrm{R}^{2}=-(R)-\mathrm{Trp}-\mathrm{OCH}_{3} \mathbf{1 6 l} \longleftarrow \mathrm{MeOH}$

Scheme 6

Using this procedure 14,15-dihydrovindoline and 14,15-cyclopropano vindoline were also coupled with (L)-tryptophan methyl ester, yielding compounds $\mathbf{1 6 e}$ and $\mathbf{1 6} \mathbf{i}$, respectively.

The derivatives containing (D)-tryptophan methyl ester (16c, $16 \mathrm{~g}, 16 \mathrm{k}$ ) were synthesized analogously. In the case of compounds 16a, 16c, 16e, 16g, 16i and 16k, the bromo substituent was removed from position 10 by hydrogenolysis to give compounds $\mathbf{1 6 b}, \mathbf{1 6 d}, \mathbf{1 6 f}, \mathbf{1 6 h}, \mathbf{1 6 j}$ and $\mathbf{1 6 l}$, respectively.

The influence of the different modifications of the ring system and/or the conjugation with tryptophan on the in vitro cytostasis of HL-60 human leukemia cells was analysed by using MTT assay [49] (Table 1).

\subsection{Vinblastine and vincristine condensed with a cyclopropane ring [50]}

In the course of the synthetic investigations of dimeric Vin$c a$ alkaloids various methods have been elaborated to synthesize new derivatives of vinblastine (6) and vincristine (7) with improved therapeutic effect exhibiting higher selectivity and lower toxicity [43,51].

One of the structural modifications was very simple and only a little part of the large molecule was changed; 14,15-dihydrovinblastine (17) having a saturated vindoline ring was simply prepared by catalytic hydrogenation of vinblastine (6) (Scheme 7), and the antitumor activity almost ceased [47].

The introduction of a cyclopropane ring in place of the $\mathrm{C}(14)=\mathrm{C}(15)$ carbon carbon double bond of the vindoline ring (18) can be regarded as a minor change within the overall molecular framework of vinblastine; however, the electronic nature of this small ring has entirely special properties. According to NMR and X-ray-crystallographyc studies, the electronic structure of the cyclopropane ring cannot be described in terms of classical methods [22,23].

Our enquiry was aimed at finding out how the introduction of this unique structural system into vinblastine and vincristine will influence their biological effects. To that end we 
Table 1 Cytostatic activity of vindoline derivatives on HL-60 cells.

\begin{tabular}{|c|c|c|}
\hline Compound & Code & IC50 $(\mu \mathrm{M}) \pm$ s.d. \\
\hline Methyl- $\{N$-[10-bromo-17-O-desacetyl-16-des(methoxycarbonyl)--vindoline-16-carbonyl]-L-Trp $\}$ & $16 \mathbf{a}$ & $56.8 \pm 9.8$ \\
\hline Methyl- $\{N$-[10-bromo-17-O-desacetyl-16-des(methoxycarbonyl)--vindoline-16-carbonyl]-D-Trp $\}$ & $16 \mathrm{c}$ & $73.8 \pm 10.4$ \\
\hline Methyl- $\{N$-[17-O-desacetyl-16-des(methoxycarbonyl)--vindoline-16-carbonyl]-L-Trp $\}$ & $16 \mathrm{~b}$ & $54.3 \pm 6.7$ \\
\hline Methyl- $\{N$-[17-O-desacetyl-16-des(methoxycarbonyl)--vindoline-16-carbonyl]-D-Trp $\}$ & $16 d$ & $73.0 \pm 2.3$ \\
\hline Methyl- $\{N$-[10-bromo-14,15-dihydro-17-O-desacetyl-16--des(methoxycarbonyl)vindoline-16-carbonyl]-L-Trp $\}$ & $16 \mathrm{e}$ & $60.1 \pm 15.0$ \\
\hline Methyl- $\{N$-[14,15-dihydro-17-O-desacetyl-16-des(methoxycarbonyl)--vindoline-16-carbonyl]-L-Trp $\}$ & $16 f$ & $27.5 \pm 1.5$ \\
\hline Methyl- $\{N$-[10-bromo-14,15-dihydro-17-O-desacetyl-16--des(methoxycarbonyl)vindoline-16-carbonyl]-D-Trp $\}$ & $16 \mathrm{~g}$ & $60.8 \pm 1.3$ \\
\hline Methyl- $\{N$-[14,15-dihydro-17-O-desacetyl-16-des(methoxycarbonyl)vindoline-16-carbonyl]-D-tryptophanate $\}$ & $16 \mathrm{~h}$ & $78.4 \pm 9.7$ \\
\hline Methyl- $\{N$-[10-bromo-14(S),15(R)-cyclopropano-17-O-desacetyl--16-des(methoxycarbonyl)vindoline-16-carbonyl]-L-Trp $\}$ & $16 \mathbf{i}$ & $75.3 \pm 2.3$ \\
\hline Methyl- $\{N$-[10-bromo-14(S),15(R)-cyclopropano-17-O-desacetyl--16-des(methoxycarbonyl)vindoline-16-carbonyl]-D-Trp $\}$ & $16 \mathbf{k}$ & $72.6 \pm 4.0$ \\
\hline Methyl- $\{N$-[14(S),15(R)-cyclopropano-17-O-desacetyl-16--des(methoxycarbonyl)vindoline-16-carbonyl]-L-Trp $\}$ & $16 \mathbf{j}$ & $77.1 \pm 8.1$ \\
\hline Methyl- $\{N$-[14(S),15(R)-cyclopropano-17-O-desacetyl-16--des(methoxycarbonyl)vindoline-16-carbonyl]-D-Trp $\}$ & 161 & $>100$ \\
\hline Vindoline & 8 & $>100$ \\
\hline
\end{tabular}



$\mathrm{R}=\mathrm{CH}_{3} ; \mathbf{6}$, Vinblastine
$\mathrm{R}=\mathrm{CHO} ;$, Vincristine



14,15-Dihydrovinblastine, 17



14,15-Cyclopropanovinblastine, 18

Scheme 7

set out to synthesize 14,15-cyclopropanovinblastine (18) and some derivatives thoseof.

A number of cyclopropanation reactions are known in the literature [28] such as the Simmon-Smith reaction [29,30] and its variants, e.g. that involving triisobutylaluminium [52] or diazomethane in the presence of a catalyst [32].

First we attempted the direct cyclopropanation of vinblastine (VBL) (6) and vincristine (VCR) (7). In the course of the reaction of vinblastine (6) using diiodomethane in the presence of diethylzinc in dichloromethane solution no cyclopropanation occurred; a quaternary salt (19) was isolated in 18\% yield and two rearranged products were found in a 2:1 mixture by NMR spectroscopy, vinamidine [53-56] (21) and cyclovinblastine [58] (23) (Scheme 8). The latter are known in the literature and were identified by NMR.

Similarly, when treating vincristine (7) under such reaction conditions the corresponding $\mathbf{2 0}$ quaternary salt was isolated in 9\% yield, and $N$-formylcatharinine [57] (22) and 




$\mathrm{R}=\mathrm{CH}_{3} ; 6$

$\mathrm{R}=\mathrm{CHO} ; 7$



$\mathrm{R}=\mathrm{CH}_{3} ; 21$, vinamidine

$\mathrm{R}=\mathrm{CHO} ; \mathbf{2 2}, \mathrm{N}$-formylcatharinine
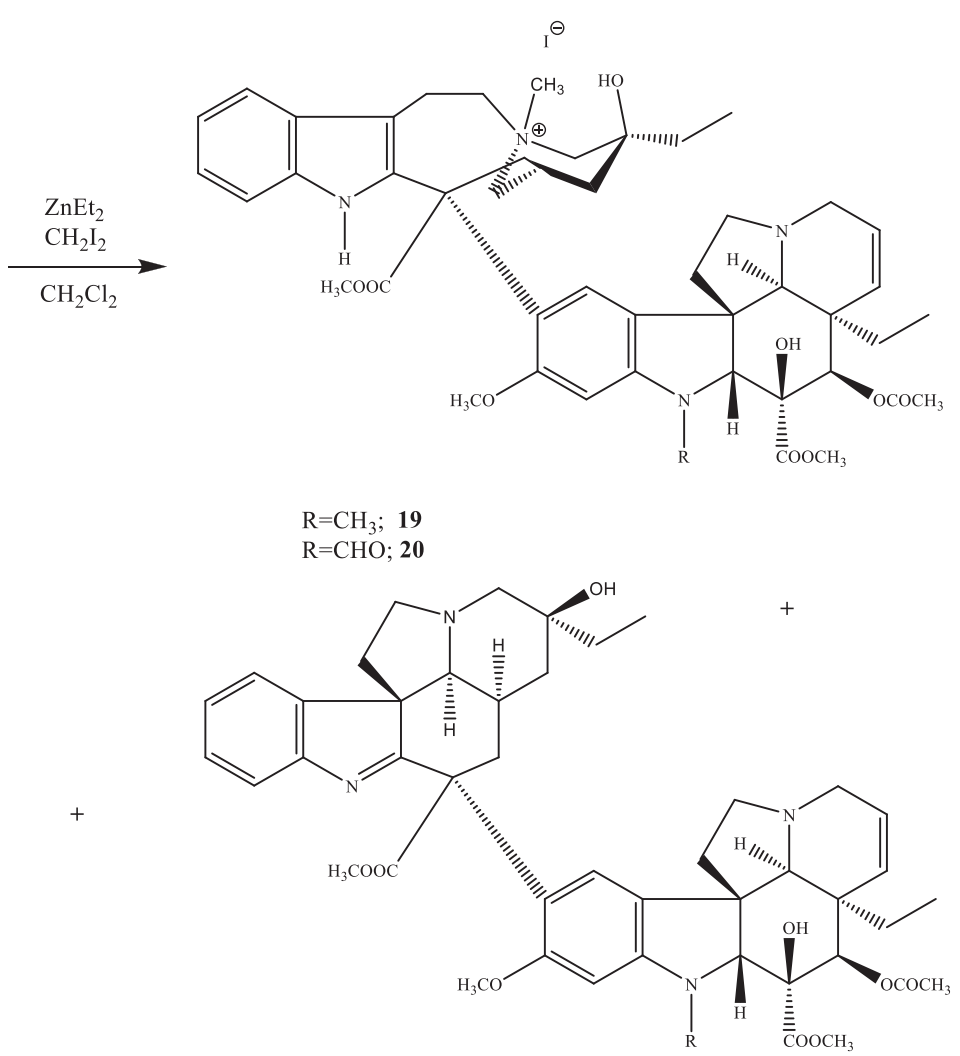

$\mathrm{R}=\mathrm{CH}_{3} ; 23$, cyclovinblastine $\mathrm{R}=\mathrm{CHO} ; 24$, cyclovincristine

Scheme 8

cyclovincristine [58] (24) were identified by NMR spectroscopy as a 1:1 mixture. Using the triisobutylaluminium method [52], only decomposed products were obtained from the reaction mixtures.

Therefore the coupling reaction traditionally used to obtain dimeric alkaloids was selected to synthesize the expected cyclopropanated derivatives.

As the result of the reaction of vindoline $(\mathbf{8})$ with diiodomethane in the presence of diethylzinc in dichloromethane solution, only the cyclopropanated dimer (25) could be isolated (Scheme 9) with 6\% yield.

The 14,15-cyclopropano derivative of 10-bromovindoline (26) was previously prepared by us [40] from 10-bromovindoline [44] (10) in the reaction with diiodomethane and with diethylzinc in dichloromethane (Scheme 9). 10-Bromo-14,15cyclopropanovindoline (26) was treated in methanol with sodium borohydride in the presence of palladium on charcoal, which resulted in the expected 14,15-cyclopropanovindoline (27) unsubstituted in position 10.

Compound 27 proved to be suitable for the coupling reaction with catharanthine to give cyclopropano-vinblastine and cyclopropano-vincristine.

The next step in our synthetic work was to prepare the cyclopropanated anhydrovinblastine (28), which can be an important intermediate in the synthesis of further derivatives (Scheme 10). 14,15-Cyclopropanovindoline was coupled with catharanthine
(9) by the method of biomimetic iron(III)-promoted coupling reaction $[59,60]$. The procedure used by us is the traditional coupling reaction for the preparation of dimeric alkaloids.

Catharanthine (9) and 14,15-cyclopropanovindoline (27) were dissolved in diluted aqueous hydrochloric acid solution together with the non-nucleophilic cosolvent 2,2,2-trifluoroethanol (Scheme 10). The reaction was carried out at room temperature. Sodium borohydride was used as the reducing agent in water at $0{ }^{\circ} \mathrm{C} .14,15$-Cyclopropanoanhydrovinblastine (28) was obtained in $51 \%$ yield and was isolated by preparative thin-layer chromatography. From 28 base the sulfate salt was prepared immediately.

Hydration of the obtained anhydrovinblastine derivative (28) to 14,15-propanovinblastine (29) was carried out by the known oxidation protocol $[69,60]$ utilizing the oxalate salt $\mathrm{Fe}_{2}(\mathrm{ox})_{3}$ and air at $0{ }^{\circ} \mathrm{C}$ in water, diluted aqueous hydrochloric acid and 2,2,2-trifluoroethanol mixture. After purification the crude product with preparative thin-layer chromatography was transformed into the sulfate salt. 14,15-Cyclopropanovinblastine (29) was obtained in $13 \%$ yield.

The new cyclopropano derivative of vinblastine (29) was oxidized [61] to 14,15-cyclopropanovincristine (30) by chromium(VI)oxide in acetone-acetic acid solution in the presence of acetic anhydride at $-60{ }^{\circ} \mathrm{C}$. The crude product which contained some $N$-demethylvincristine was reformylated with formic acid/acetic anhydride. After isolation the product by 




$\mathrm{R}=\mathrm{H} ; 8$

$\mathrm{R}=\mathrm{Br} ; \mathbf{1 0}$


$\mathrm{H}_{3} \mathrm{COCO}^{\prime \prime \prime \prime \prime) ~}$

25

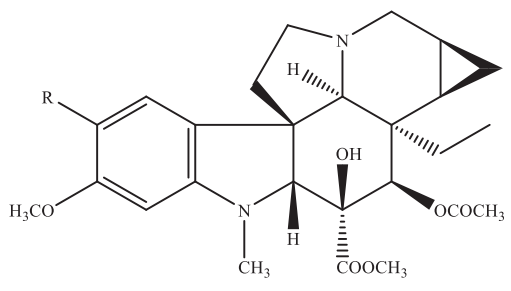

$$
\begin{aligned}
& \mathrm{R}=\mathrm{Br} ; \mathbf{2 6} \longrightarrow \begin{array}{l}
\mathrm{Pd} / \mathrm{C} \\
\mathrm{NaBH}_{4}
\end{array} \\
& \mathrm{R}=\mathrm{H} ; \mathbf{2 7} \longleftarrow \begin{array}{l}
\mathrm{NaBH}_{4} \\
\mathrm{CH}_{3} \mathrm{OH}
\end{array}
\end{aligned}
$$

Scheme 9



28



29



30

Scheme 10

preparative thin-layer chromatography, sulfate salt was prepared and the expected product (30) was obtained in 52\% yield.

The new compounds synthesized by us were sent to the US National Institute of Health (NIH) where they were subjected to pharmacological investigations. These experiments on 56 different tumor cell lines embracing 9 frequently occurring tumor types demonstrated the therapeutic activity of these substances in comparison with other known effective catharanthus alkaloids.
Tumor types and cell lines were the following: leukemia (CCRF-CEM, HL(60)-TB, K-562, MOLT-4, RPMI-8226, SR), non-small cell lung cancer (A549/ATCC, EKVX, HOP-62, HOP-92, NCI-H226, NCI-H23, NCI-H322M, NCI-H460, NCIH522), colon cancer (COLO 205, HCC-2998, HCT-116, HCT15, HT-29, KM12, SW-620), CNS cancer (SF-268, SF-295, SF-539, SNB-19, SNB-75, U251), melanoma (LOX IMVI, MALME-3M, M14, MDA-MB-435, SK-MEL-2, SK-MEL-28, 
Table 2 Inhibition effect of cyclopropanated dimer alkaloids against different cell lines of different tumors

\begin{tabular}{|c|c|c|c|c|}
\hline & VBL & cVBL (29) & VCR & cVCR (30) \\
\hline \multicolumn{5}{|l|}{ Leukemia } \\
\hline HL-60(TB) & 2.9 & -30.9 & & \\
\hline SR & 10.2 & -20.6 & & \\
\hline \multicolumn{5}{|c|}{ Non-small cell lung cancer } \\
\hline HOP-92 & & & 72.3 & -0.4 \\
\hline NCI-H226 & 48.9 & -25.3 & & \\
\hline NCI-H23 & & & 290.4 & 6.3 \\
\hline \multicolumn{5}{|l|}{ Colon cancer } \\
\hline COLO 205 & -50.7 & -73.3 & -57.2 & -87.9 \\
\hline HCT-116 & 1.7 & -22.4 & & \\
\hline HT29 & & & -3 & -21.1 \\
\hline KM12 & & & 5.8 & -17.5 \\
\hline \multicolumn{5}{|l|}{ CNS cancer } \\
\hline SF-295 & 12.2 & -15.1 & & \\
\hline SNB-19 & 43.8 & 24 & & \\
\hline SNB-75 & 5.3 & -14.6 & & \\
\hline \multicolumn{5}{|l|}{ Melanoma } \\
\hline M14 & -15.6 & -72 & & \\
\hline MDA-MB-435 & & & -43.7 & -53.2 \\
\hline SK-MEL-2 & & & 58 & 11.6 \\
\hline SK-MEL-5 & -61.3 & -80.1 & & \\
\hline \multicolumn{5}{|l|}{ Ovarian cancer } \\
\hline OVCAR-3 & & & -41.4 & -53.6 \\
\hline \multicolumn{5}{|l|}{ Renal cancer } \\
\hline CAKI-1 & 26.8 & 13.2 & & \\
\hline \multicolumn{5}{|l|}{ Prostate cancer } \\
\hline DU-145 & & & -42.5 & -41.4 \\
\hline \multicolumn{5}{|l|}{ Breast cancer } \\
\hline BT-549 & 34.2 & -47.2 & & \\
\hline
\end{tabular}

VBL:vinblastine, VCR: vincristine,

cVBL: 14,15-cyclopropano-vinblastine (29), cVCR: 14,15-cyclopropano-vincristine (30)

SK-MEL-5, UACC-257, UACC-62), ovarian cancer (IGROV1, OVCAR-3, OVCAR-4, OVCAR-8, NCI/ADR-RES, SK-OV-3), renal cancer (786-0, A498, ACHN, CAKI-1, RXF 393, SN12C, TK-10, UO-31), prostate cancer (PC-3, DU-145), breast cancer (MCF7, MDA-MB-231/ATCC, HS 578T, BT498, T-47D, MDA-MB-468).

The NCI screening procedures were described [62] as were the origins and processing of the cell lines [62-64]. In Table 2 percentages of growths are listed for the reference alkaloids and the appropriate cyclopropano derivatives at the concentration of $10^{-5} \mathrm{M}$. The bigger negative numbers show more significant decrease of cell number or stronger inhibition effects.

According to Table 2 cyclopropano-vinblastine (29) has significant tumor cell inhibiting effect in leukemia, non-small-cell lung cancer, colon cancer, melanoma and breast cancer, cyclopropano-vincristine (30) has significant tumor cell inhibiting effect in colon cancer, melanoma, ovarian cancer and prostate cancer.

\section{Acknowledgement}

The authors are grateful to OTKA (Hungarian Academic Research Found Grant K 68734) and to Gedeon Richter Plc for financial assistance.

\section{References}

[1] Keglevich, P., Kovács, P., Hazai, L., Sánta, Zs., Dubrovay, Zs., Háda, V., Szántay, Cs. Jr., Kalaus, Gy.,Szántay, Cs. "A New Derivative of Galanthamine: Methylene Insertion into the Aromatic Ring in Place of Cyclopropanation." Heterocycles. 84 (2). pp. 1171-1178. 2012. DOI: $10.3987 / \mathrm{com}-11-\mathrm{s}(\mathrm{p}) 98$

[2] Marco-Contelles, J., do Carmo Carreiras, M., Rodríguez, C., Villarroya, M., García, A. G. "Synthesis and Pharmacology of Galanthamine." Chemical Reviews. 106 (1). pp. 116-133. 2006. DOI: $10.1021 / \mathrm{cr} 040415 \mathrm{t}$

[3] Houghton, P. J., Ren, Y., Howes, M. J. "Acetylchloinesterase Inhibitors from Plants and Fungi." Natural Product Reports. 23 (2). pp. 181-199. 2006.

DOI: 10.1039/b508966m 
[4] Darwesh, S., Walsh, R, Kumar, R, Caines, A, Roberts, S, Magee, D, Rockwood, K, Martin, E. "Inhibition of Human Cholinestereases by Drugs Used to Treat Alzheimer Disease." Alzheimer Disease \& Associated Disorders. 17 (2). pp. 117-126. 2003.

[5] Maeliczke, A., Samochocki, M., Jostock, R., Fehrenbacher, A., Ludwig, J., Albuquerque, E. X., Zerlin, M. "Allosteric sensitization of nicotinic receptors by galantamine, a new treatment strategy for Alzheimer's disease." Biological Psychiatry. 49 (3). pp. 279-288. 2001. DOI: 10.1016/s0006-3223(00)01109-4

[6] Ago, Y., Koda, K., Takuma, K., Matsuda, T. "Pharmacological Aspects of the Acetylcholinesterase Inhibitor Galantamine." Journal of Pharmacological Sciences. 116 (1). pp. 6-17. 2011.

DOI: 10.1254/jphs.11R01CR

[7] Czollner, L., Frantsits, W., Küenburg, B., Hedenig, U., Fröhlich, J., Jordis, U. "New kilogram-synthesis of the anti-Alzheimer drug (-)-galanthamine." Tetrahedron Letters. 39 (15). pp. 2087-2088. 1988. DOI: 10.1016/s0040-4039(98)00294-9

[8] Trost, B. M., Tang, W., Toste, F. D. "Divergent Enantioselective Synthesis of (-)-Galanthamine and (-)-Morphine. Journal of the American Chemical Society. 127 (42). pp. 14785-14803. 2005. DOI: $10.1021 / \mathrm{ja} 054449+$

[9] Node, M., Kodama, S., Hamashima, Y., Katoh, T., Nishide, K., Kajimoto, T. "Biomimetic Synthesis of $( \pm)$-Galanthamine and Asymmetric Synthesis of (-)-Galanthamine Using Remote Asymmetric Induction." Chemical \& Pharmaceutical Bulletin. 54 (12). pp. 1662-1669. 2006. DOI: $10.1248 / \mathrm{cpb} .54 .1662$

[10] Ishikawa, T., Kudo, K., Kuroyabu, K., Uchida, S., Kudoh, T., Saito, S. "Domino double Michael-Claisen cyclizations: a powerful general tool for introducing quaternary stereocenters at C(4) of cyclohexane-1,3-diones and total synthesis of diverse families of sterically congested alkaloids." The Journal of Organic Chemistry. 73 (19). pp. 7498-7508. 2008. DOI: 10.1021/jo801316s

[11] Magnus, P., Sane, N., Fauber, B. P., Lynch, V. "Concise Syntheses of (-)-Galanthamine and ( \pm )-Codeine via Intramolecular Alkylation of a Phenol Derivative." Journal of the American Chemical Society. 131 (44). pp. 16045-16047. 2009.

DOI: $10.1021 /$ ja9085534

[12] Chang, J. K., Kang, H.-U., Jung, I.-H., Cho, C.-G. "Total Synthesis of $( \pm)$-Galanthamine via a C3-selective Stille Coupling and IMDA Cycloaddition Cascade of 3,5-dibromo-2-pyrone." Organic Letters. 12 (9). pp. 2016-2018. 2010.

DOI: $10.1021 / \mathrm{ol} 100617 \mathrm{u}$

[13] Kato, T., Tanimoto, H., Yamada, H., Chida, N. "Total Synthesis of (+)and (-)-Galanthamine." Heterocycles. 82 (1). pp. 563-579. 2010. DOI: $10.3987 /$ com-10-s(e)27

[14] Chen, P., Bao, X., Zhang, L.-F., Ding, M., Han, X.-J., Li, J., Zhang, G.-B., Tu, Y.-Q., Fan, C.-A. "Asymmetric Synthesis of Bioactive Hydrodibenzofuran Alkaloids: (-)-Lycoramine, (-)-Galanthamine, and (+)-Lunarine." Angewandte Chemie International Edition. 50 (35). pp. 8161-8166. 2011. DOI: 10.1002/anie.201103198

[15] Lewin, A. H., Szewczyk, J., Wilson, J. W., Carroll, F. I. "Galanthamine analogs: $6 \mathrm{H}$-benzofuro[3a,3,2,-e,f][1]benzazepine and $6 \mathrm{H}$ benzofuro[3a,3,2,-e,f][3]benzazepine." Tetrahedron. 61 (30). pp. 7144-7152. 2005.

DOI: $10.1016 /$ j.tet.2005.05.055

[16] Treu, M., Jordis, U., Mereiter, K. "12H-[2]-Benzothiepino[6,5a,5bc]benzofuran: Synthesis of a Sulfur-Analog of Galanthamine." Heterocycles. 55 (9). pp. 1727-1735. 2001.

DOI: $10.3987 /$ com-01-9278
[17] Guillou, C., Bernard, C., Gras, J. L. "Process for the total synthesis of galanthamine, analogues and derivatives thereof." WO 2002/102803, 2002. Chemical Abstracts. 138. p. 39446. 2002.

[18] Vanlaer, S., De Borggraeve, W. M., Compernolle, F. "Synthesis of Spirocyclic Pyridoazepines as Analogues of Galanthamine by $\mathrm{Nu}$ cleophilic Aromatic Substitution of 3-substituted 2-chloropyridines." European Journal of Organic Chemistry. 30. pp. 4995-4998. 2007. DOI: 10.1002/ejoc.200700614

[19] Vanlaer, S., De Borggraeve, W. M., Voet, A., Gielens, C., De Maeyer, M. Compernolle, F. "Spirocyclic Pyridoazepine Analogues of Galanthamine: Synthesis, Modelling Studies and Evaluation as Inhibitors of Acetylcholinesterase." European Journal of Organic Chemistry. 15. pp. 2571-2581. 2008. DOI: $10.1002 /$ ejoc. 200800062

[20] Herlem, D. Martin, M.-T., Thal, C., Guillou, C. "Synthesis and structure-activity relationships of open D-ringalanthamine analogues." Bioorganic \& Medicinal Chemistry Letters. 13 (14). pp. 2389-2391. 2003.

DOI: $10.1016 / \mathrm{s} 0960-894 x(03) 00397-4$

[21] Yamamoto, N., Fujii, H., Imaide, S., Hirayama, S., Nemoto, T., Inokoshi, J., Tomoda, H., Nagase, H. "Synthesis of (-)-Homogalanthamine from Naltrexone." Journal of Organic Chemistry. 76 (7). pp. 2257-2260. 2011.

DOI: $10.1021 /$ jo1022487

[22] Weigert, F. J., Roberts, J. D. "Nuclear magnetic resonance spectroscopy. Carbon-carbon coupling in cyclopropane derivatives." Journal of American Chemical Society. 89 (23). pp. 5962-5963. 1967.

[23] Wiberg, K. B. "Bent bonds in organic compounds." Accounts of Chemical Research. 29 (5). pp. 229-234. 1996.

DOI: $10.1021 / \operatorname{ar} 950207 \mathrm{a}$

[24] Lebel, H., Marcoux, J.-F., Molinaro, C., Charette, A. B. "Stereoselective Cyclopropanation Reactions." Chemical Reviews. 103 (4). pp. 977-1050. 2003.

DOI: $10.1021 / \mathrm{cr} 010007 \mathrm{e}$

[25] Faust, R. "Fascinating Natural and Artificial Cyclopropane Architectures." Angewandte Chemie International Edition. 40 (12). pp. 2251 2253. 2001.

DOI: 10.1002/1521-3773(20010618)40:12<2251::aidanie2251>3.0.co;2-r

[26] Wessjohann, L. A., Brandt, W., Thiemann, T. "Biosynthesis and Metabolism of Cyclopropane Rings in Natural Compounds." Chemical Reviews. 103 (4). pp. 1625-1647. 2003

DOI: $10.1021 / \mathrm{cr} 0100188$

[27] Yoshida, K., Yamaguchi, K., Mizuno, A., Unno, Y., Asai, A., Sone, T., Yokosawa, H., Matsuda, A., Arisawa, M., Shuto, S. "Three-dimensional structure-activity relationship study of belactosin A and its stereo- and regioisomers: development of potent proteasome inhibitors by a stereochemical diversity-oriented strategy." Organic \& Biomolecular Chemistry. 7 (9). pp. 1868-1877. 2009. DOI: 10.1039/B900384C

[28] Donaldson, W. A. "Synthesis of cyclopropane containing natural products." Tetrahedron. 57 (41). pp. 8589-8627. 2001. DOI: 10.1016/s0040-4020(01)00777-3

[29] Tori, M., Hamaguchi, T., Aoki, M., Sono, M., Asakawa, Y. "Isolation, structure, and synthesis of chenopodanol and the absolute configuration of chenopodene and chenopodanol." Canadian Journal of Chemistry. 75 (6). pp. 634-640. 1997.

DOI: $10.1139 / \mathrm{v} 97-077$ 
[30] Lorenz, J. C., Long, J., Yang, Z., Xue, S., Xie, Y., Shi, Y. "A Novel Class of Tunable Zinc Reagents ( $\mathrm{RXZnCH}_{2} \mathrm{Y}$ ) for Efficient Cyclopropanation of Olefins." The Journal of Organic Chemistry. 69 (2). pp. 327-334. 2004

DOI: $10.1021 /$ jo030312y

[31] Moldvai, I. Gács-Baitz, E., Balázs, M., Incze, M., Szántay, Cs. "Chemistry of indoles carrying a basic function. Part $3^{1}$ Synthesis of spiro \{cyclopropane-1,3'[3H]indol\}-2'(1H)-ones with antihypoxic effects." Archiv der Pharmazie. 329 (12). pp. 541-549. 1996. DOI: 10.1002/ardp.19963291206

[32] Incze, M., Dörnyei, G., Moldvai, I., Temesvári-Major, E., Egyed, O., Szántay, Cs. "New routes to clavine-types ergot alkaloids. Part 2: Synthesis of the last, so far not yet synthesized member of the clavinet alkaloid family, $( \pm)$-cycloclavine." Tetrahedron. 64 (13). pp. 2924-2929. 2008.

DOI: $10.1016 / j$.tet.2008.01.101

[33] Dzhemilev, U. M., Dokichev, V. A., Sultanov, S. Z., Sadykov, R. A., Tolstikov, G. A., Nefedov, O. M. "Synthesis of cyclohepta-1,3,5trienes via reaction of aromatic hydrocarbons with diazo compounds in the presence of transition metal complexes." Bulletin of Academy of Scienes of the USSR Division of Chemical Science. 40 (5). pp. 945 950. 1991.

DOI: $10.1007 / \mathrm{bf00961355}$

[34] Thummel, R. P., Chayangkoon, P. "Preparation and properties of annelated tropylium salts." The Journal of Organic Chemistry. 48 (4). pp. 596-601. 1983.

DOI: $10.1021 /$ jo00152a037

[35] Müller, E., Kessler, H., Fricke, H., Kiedaisch, W. "Kupfersalzkatalysierte Homologisierung von Benzolderivaten mit Diazomethan zu Cycloheptatrien-Derivaten. (Copper salt-catalyzed homologization of benzene derivatives with diazomethane to cycloheptatriene derivatives.)" Liebigs Annalen der Chemie. 675. pp. 63-73. 1964. (In German) DOI: $10.1002 /$ jlac. 19646750109

[36] Komatsu, K., Takeuchi, K., Arima, M., Waki, Y., Shirai, S., Okamoto, K. "Syntheses and Properties of Di-, Tri-, and Tetracyclopropyltropylium and Di- and Tri-t-butyltropylium Ions." Bulletin of the Chemical Society of Japan. 55 (10). pp. 3257-3261. 1982.

DOI: $10.1246 /$ bcsj. 55.3257

[37] Katritzky, A. R., Musierowicz, S. "Reaction of diazomethane of 2,2'-azopyridines." Journal of the Chemical Society C: Organic. pp. 78-79. 1966

DOI: $10.1039 / \mathrm{j} 39660000078$

[38] a) Hashimoto, N., Aoyama, T., Shioiri, T. "New methods and reagents in organic synthesis. 14. A simple efficient preparation of methyl esters with trimethylsilyldiazomethane (TMSCHN2) and its application to gas chromatographic analysis of fatty acids." Chemical \& Pharmaceutical Bulletin. 29 (5). pp. 1475-1478. 1981.

DOI: $10.1248 / \mathrm{cpb} .29 .1475$

[38] b) Aoyama, T.,Terasawa, S., Sudo, K., Shioiri, T. "New methods and reagents in organic synthesis. 46. Trimethylsilyldiazomethane: A convenient reagent for the O-methylation of phenols and enols." Chemical \& Pharmaceutical Bulletin. 32 (9). pp. 3759-3760. 1984. DOI: $10.1248 / \mathrm{cpb} .32 .3759$

[39] Hartz, N., Prakash, G. K. S., Olah G. A. "Mechanism of the reaction of methylene with benzene: a study of kinetic hydrogen isotop effects and theoretical calculations." Journal of the American Chemical Society. 115 (3). pp. 901-905. 1993.

DOI: $10.1021 / \mathrm{ja} 00056 \mathrm{a} 013$
[40] Keglevich, P., Hazai, L., Gorka-Kereskényi, Á., Péter, L., Gyenese, J., Lengyel, Zs., Kalaus, Gy., Dubrovay, Zs., Dékány, M., Orbán, E., Szabó, I., Bánóczi, Z., Szántay, Cs. Jr., Szántay, Cs. "Synthesis and in vitro Antitumor Effect of New Vindoline Derivatives Coupled with Amino Acid Esters." Heterocycles. 87 (11). pp. 2299-2317. 2013. DOI: $10.3987 /$ com-13-12827

[41] Brossi, A., Suffness, M. "The Alkaloids." New York: Academic Press Inc. p. 240. 1990.

[42] Sisodya, P. S. "Plant derived anticancer agents: a review." International Journal of Research and Development in Pharmacy \& Life Sciences. 2 (2). pp. 293-308. 2013.

[43] Keglevich, P., Hazai, L., Kalaus, Gy., Szántay, Cs. "Modifications on the Basic Skeletons of Vinblastine and Vincristine." Molecules. 17 (12). pp. 5893-5914. 2012 DOI: $10.3390 /$ molecules 17055893

[44] Gorka-Kereskényi, Á., Szabó, L., Hazai, L., Lengyel, M., Szántay, Cs. Jr., Sánta, Zs., Kalaus, Gy., Szántay, Cs. "Aromatic Electrophilic Substitutions on Vindoline." Heterocycles. 71 (7). pp. 1553-1563. 2007.

DOI: $10.3987 / \mathrm{com}-07-11049$

[45] Rao, K. S. P. B., Collard, M. P. M., Dejonghe, J. P. C., Atassi, G., Hannart, J. A., Trouet, A. "Vinblastin-23-oyl amino acid derivatives: chemistry, physicochemical data, toxicity, and antitumor activities against P388 and L1210 leukemias." Journal of Medicinal Chemistry. 28 (8). pp. 1079-1088. 1985

DOI: $10.1021 / \mathrm{jm} 00146 \mathrm{a} 017$

[46] Bánóczi, Z., Gorka-Kereskényi, Á., Reményi, J., Orbán, E., Hazai, L., Tökési, N., Oláh, J., Ovádi, J., Béni, Z., Háda, V., Szántay, Cs. Jr., Hudecz, F., Kalaus, Gy., Szántay, Cs. "Synthesis and in Vitro Antitumor Effect of Vinblastine Derivative-Oligoarginine Conjugates." Bioconjugate Chemistry. 21 (11). pp. 1948-1955. 2010. DOI: $10.1021 / \mathrm{bc} 100028 \mathrm{z}$

[47] Noble, R. L., Beer, M. D. C. T., Mcintyre, R. W. "Biological effects of dihydrovinblastine." Cancer. 20 (5). pp. 885-890. 1967. DOI: 10.1002/1097-0142(1967)20:5<885::aidcncr2820200549>3.0.co;2-v

[48] a) Gorman, M., Neuss, N., Biemann, K. "Vinca alkaloids. X. Structure of vindoline." Journal of the American Chemical Society. 84 (6). pp. 1058-1059. 1962. DOI: $10.1021 / \mathrm{ja} 00865 \mathrm{a} 042$

[48] b) Ishikawa, H., Elliott, G. I., Velcicky, J., Choi, Y., Boger, D. L. "Total synthesis of (-)- and ent-(+)-vindoline and related alkaloids." Journal of the American Chemical Society. 128 (32). pp. 1059610612. 2006. DOI: $10.1021 / \mathrm{ja} 061256 \mathrm{t}$

[49] Slater, T. F., Sawyer, B., Sträuli, U. "Studies on succinate-tetrazolium reductase systems: III. Points of coupling of four different tetrazolium salts III. Points of coupling of four different tetrazolium salts." Biochimica et Biophysica Acta. 77. pp. 383-393. 1963.

DOI: 10.1016/0006-3002(63)90513-4

[50] Keglevich, P., Hazai, L., Dubrovay, Zs., Dékány, M., Szántay, Cs. Jr., Kalaus, Gy., Szántay, Cs. "Bisindole Alkaloids Condensed with a Cyclopropane Ring, Part 1. 14,15-Cyclopropanovinblastine and -vincristine." Heterocycles. 89 (3). pp. 653-668. 2014. DOI: $10.3987 /$ com-13-12918

[51] Bolcskei, H., Szabo, L., Szantay, Cs. "Synthesis of Vinblastine Derivatives." Frontiers in Natural Product Chemistry. 1 (1). pp. 43-49. 2005

DOI: $10.2174 / 1574089054583849$ 
[52] Brunner, G., Elmer, S., Schröder, F. "Transition-Metal-Catalyzed Cyclopropanation of Nonactivated Alkenes in Dibromomethane with Triisobuylaluminium." European Journal of Organic Chemistry. 2011 (24). pp. 4623-4633. 2011. DOI: $10.1002 /$ ejoc. 201100528

[53] Wang, C. H., Wang, G.-C., Wang, Y., Zhang, X.-Q., Huang, X.-J., Zhang, D.-M., Chen, M.-F., Ye, W.-C. "Cytotoxic dimeric indole alkaloids from Catharanthus roseus." Fitoterapia. 83 (4). pp. 765-769. 2012.

DOI: 10.1016/j.fitote.2012.03.007

[54] Kutney, J. P., Boulet, C. A., Choi, L. S. L., Gustowski, W., McHugh, M., Nakano, J., Nikaido, T., Tsukamoto, H., Hewitt, G. M., Suen, R. "Alkaloid Production in Catharanthus roseus (L.) G. Don Cell Cultures. XIV. The Role of Unstable Dihydropyridinium Intermediates in the Biosynthesis of Bisindole Alkaloids." Heterocycles. 27 (3). pp. 613-637. 1988.

DOI: $10.3987 /$ com-87-4409

[55] Kutney, J. P., Botta, B., Boulet, C. A., Buschi, C. A., Choi, L. S. L., Golinski, J., Gumulka, M., Hewitt, G. M., Lee, G., McHuge, M., Nakano, J., Nikaido, T., Onodera, J., Perez, I., Salisbury, P., Singh, M., Suen, R., Tsukamoto, H. "Alkaloid Production in Catharanthus roseus (L.) G. Don Cell Cultures. XVI. Biotransformation of 3',4'-Anhydrovinblastine with Catharanthus roseis Cell Cultures and Enzyme Systems." Heterocycles. 27 (3). pp. 629-637. 1988.

DOI: $10.3987 / \mathrm{com}-87-4411$

[56] Kutney, J. P., Choi, L. S. L., Nakano, J., Tsukamoto, H. "Biomimetic Chemical Transformation of 3',4'-Anhydrovinblastine to Vinblastine and Related Bisindole Alkaloids." Heterocycles. 27 (8). pp. $1837-$ 1843. 1988

DOI: $10.3987 / \mathrm{com}-88-4610$

[57] Ahn, S. H., Duffel, M. W., Rosazza, J. P. N. "Oxidations of Vincristine Catalyzed by Peroxidase and Ceruloplasmin." Journal of Natural Products. 60 (11). pp. 1125-1129. 1997.

DOI: $10.1021 / \mathrm{np} 9702260$

[58] Honty, K., Demeter, Á., Szántay, Cs. Jr., Hollósi, M., Kolonits, P., Szántay, Cs. "Synthesis of Vinva Alkaloids and Related Compounds. Part XCIII. Skeletal Rearrangement of Cyclovinblastine Derivatives: Formation of a Novel Bisindole System." Heterocycles. 50 (1). pp. 169-194. 1999.

DOI: $10.3987 /$ com-98-s(h)25
[59] Boger, D. L. "Preparation of 10'-fluorinated Vinca alkaloids which provide enhanced biological activity against MDR cancer cells." WO Patent 2011/103007. Chemical Abstracts. 155. pp. 328440. 2011.

[60] Ishikawa, H., Colby, D. A., Seto, S., Va, P., Tam, A., Kakei, H., Rayl, T. J., Hwang, I., Boger, D. L. "Total Synthesis of Vinblastine, Vincristine, Related Natural Products, and Key Structural Analogues." Journal of the American Chemical Society. 131 (13). pp. 4904-4916. 2009.

DOI: $10.1021 / \mathrm{ja} 809842 \mathrm{~b}$

[61] Jovanovics, K., Szász, K., Fekete, Gy., Bittner, E., Dezséri, E., Éles, J. "Chromic acid oxidation of vinblastine sulfate to form vincristine." US Patent 3,899,493; 1975. Chemical Abstracts. 83 p. 179360. 1975.

[62] Monks, A., Scudiero, D., Skehan, P., Shoemaker, R., Paull, K., Vistica, D., Hose, C., Langley, J., Cronise, P., Vaigro-Wolff, A., GrayGoodrich, M., Campbell, H., Mayo, J., Boyd, M. "Feasibility of a High-flux Anticancer Drug Screen Using a Diverse Panel of Cultured Human Tumor Cell Lines." Journal of the National Cancer Institute. 83 (11). pp. 757-766. 1991. DOI: $10.1093 /$ jnci/83.11.757

[63] Alley, M. C., Scudiero, D. A., Monks, A., Hursey, M. L., Czerwinski, M. J., Fine, D. L., Abbott, B. J., Mayo, J. G., Shoemaker, R. H., Boyd, M. R. "Feasibility of drug screening with panels of human tumor cell lines using a microculture tetrazolium assay." Cancer Reserach. 48 (3). pp. 589-601. 1988.

[64] Shomaker, R. H., Monks, A., Alley, M. C., Scudiero, D. A., Fine, D. L., McLemore, T. L., Abbott, B. J., Paull, K. D., Mayo, J. G., Boyd, M. R. "Development of human tumor cell line panels for use of disease-orienteddrug screening." Progress in Clinical \& Biological Research. 276. pp. 265-286. 1988. 